\title{
PATH ANALYSIS
}

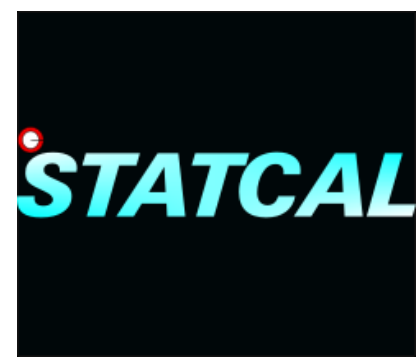

Disertai Perbandingan Hasil dengan SPSS, AMOS \& LISREL
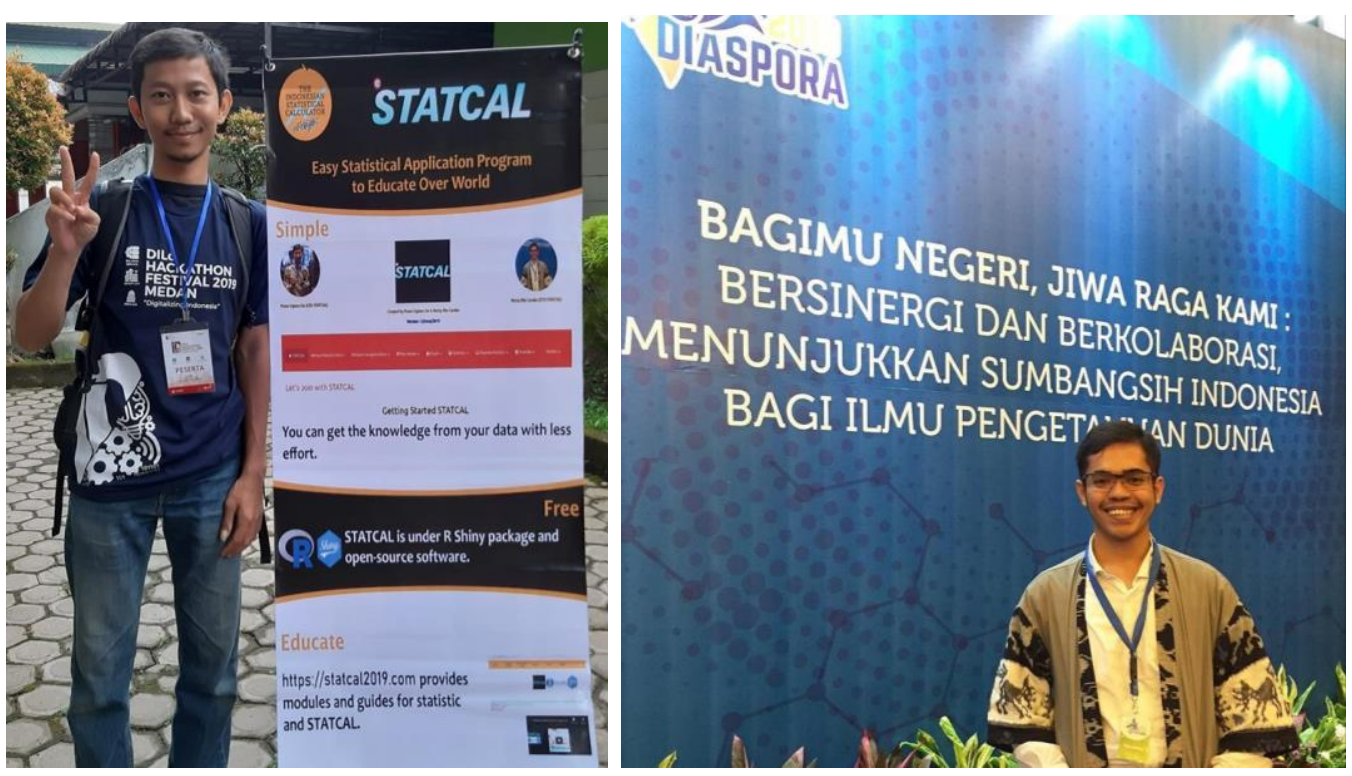

Download STATCAL di: www.statcal.org

Berbagai Artikel dan Video Pembelajaran Statistika: www.statcal2019.com

Prana Ugiana Gio (Founder STATCAL): www.pranaugi.com

Rezzy Eko Caraka (Co-Founder STATCAL): http://rezzyekocaraka.com/ 


\section{Some Addition and Improvement in STATCAL Version: August/27/2019:}

1. Logistic regression method is available. Thank's for Victor Trisman Jaya Hulu that has been contributed for this menu!!

2. Data: Shariah Stock by Jakarta Islamic Index (JII) (2014-2017) is available.Thanks for Ansuci Azzahra \& Rizki Syahputra that has been contributed for this menu!!!

3. Data: Indonesian Company Performance (9 Sectors) is available.Thanks for Ansuci Azzahra \& Rizki Syahputra that has been contributed for this menu!!!

4. Residual, Modification Indices and Graph for menu covariance based structural equation modeling (CB-SEM). Thanks for Kristiana Dewayani Samdono \& Chandra Yudistira that has been contributed for this menu!!!

5. Improvement for independent t-test menu. Thanks for Offie, Scientist at STATCAL.

6. Generate data from covariance matrix menu.

Tutorial video about STATCAL: http://statcal2019.com/

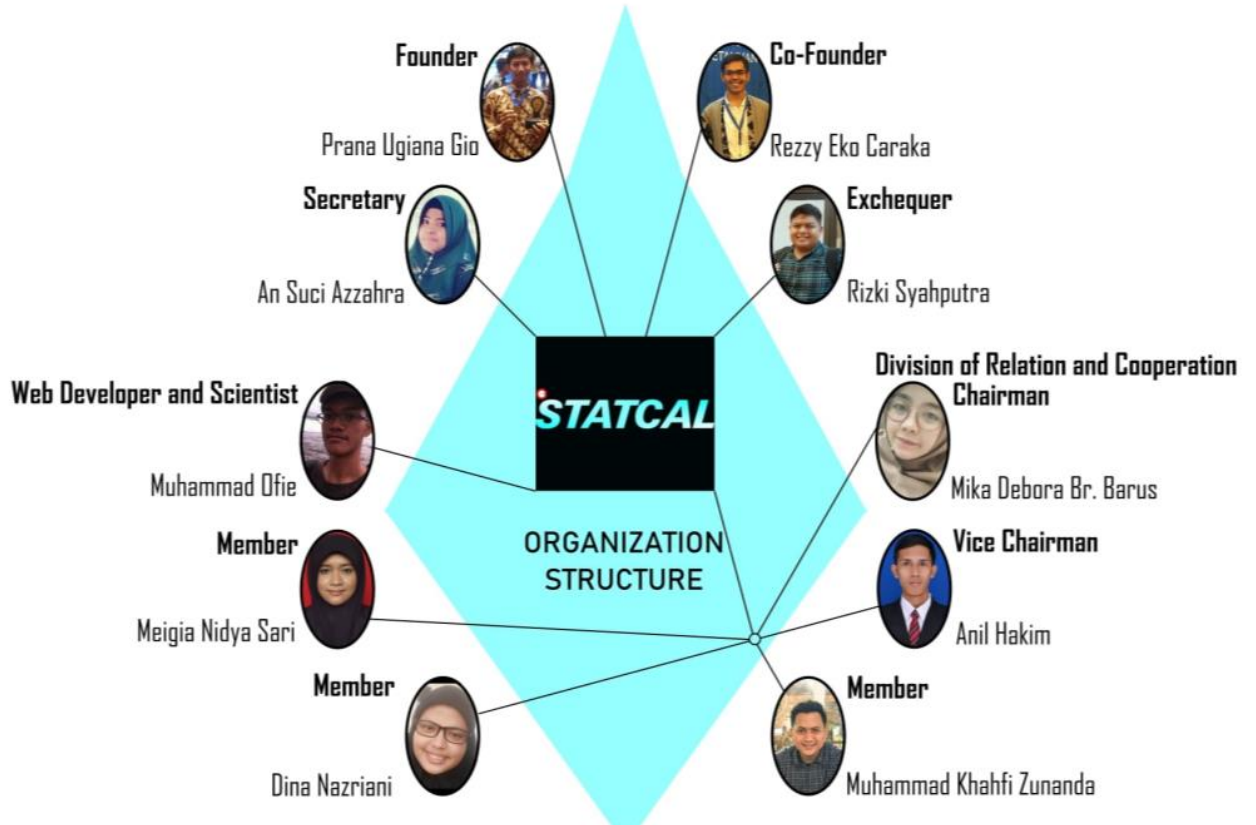

STATCAL's User in Indonesia

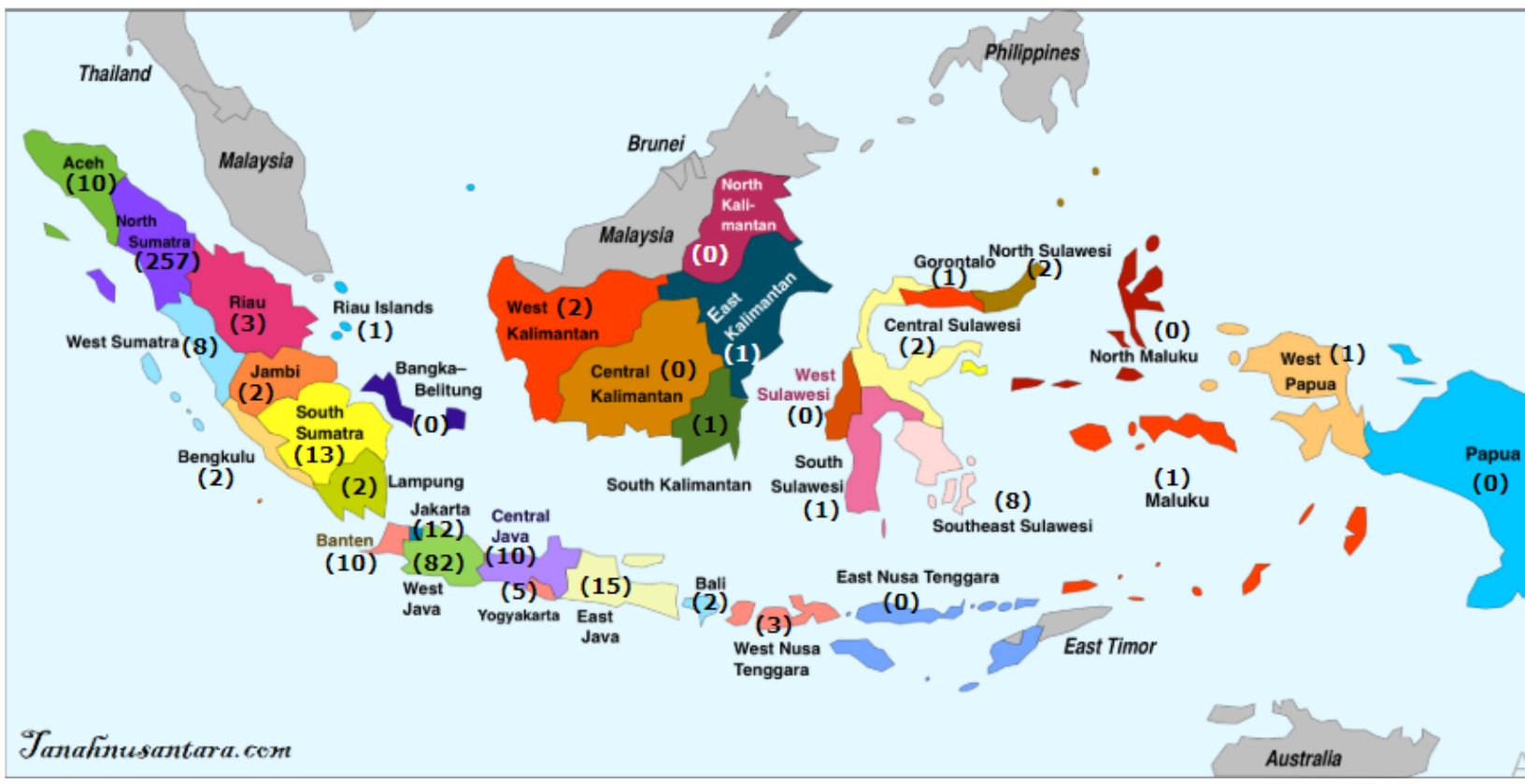




\section{BAB 18}

\section{PATH ANALYSIS}

Persamaan regresi merupakan suatu persamaan yang menerangkan atau menjelaskan hubungan antara variabel bebas dan variabel tak bebas. Misalkan diberikan persamaan regresi sebagai berikut.

$$
\text { Berat Badan }=-70,813+0.829 \text { Tinggi Badan }
$$

Berdasarkan persamaan regresi di atas, dapat diartikan ketika tinggi badan meningkat sebesar $1 \mathrm{~cm}$, maka secara rata-rata berat badan akan bertambah 0,928 kg. Dapat juga diartikan ketika tinggi badan meningkat, berat badan juga cenderung meningkat (secara rata-rata). Misalkan diberikan data sebagai berikut.

Tabel 18.1 Data Berat Badan dan Tinggi Badan (Contoh Data)

\begin{tabular}{|c|c|c|}
\hline Respoden & Berat & Tinggi \\
\hline Ugi & 67.65 & 169.43 \\
\hline Egi & 75.63 & 173.23 \\
\hline Andi & 61.12 & 165.48 \\
\hline Putri & 62.23 & 163.23 \\
\hline Intan & 64.34 & 159.75 \\
\hline Indah & 59.64 & 157.54 \\
\hline Deny & 69.75 & 164.34 \\
\hline
\end{tabular}

Berdasarkan data pada Tabel 18.1 akan dibuat persamaan regresi dengan STATCAL. Tahapan dalam STATCAL, pilih Statistics => Path Analysis Using Lavaan Package (Gambar 18.1). 


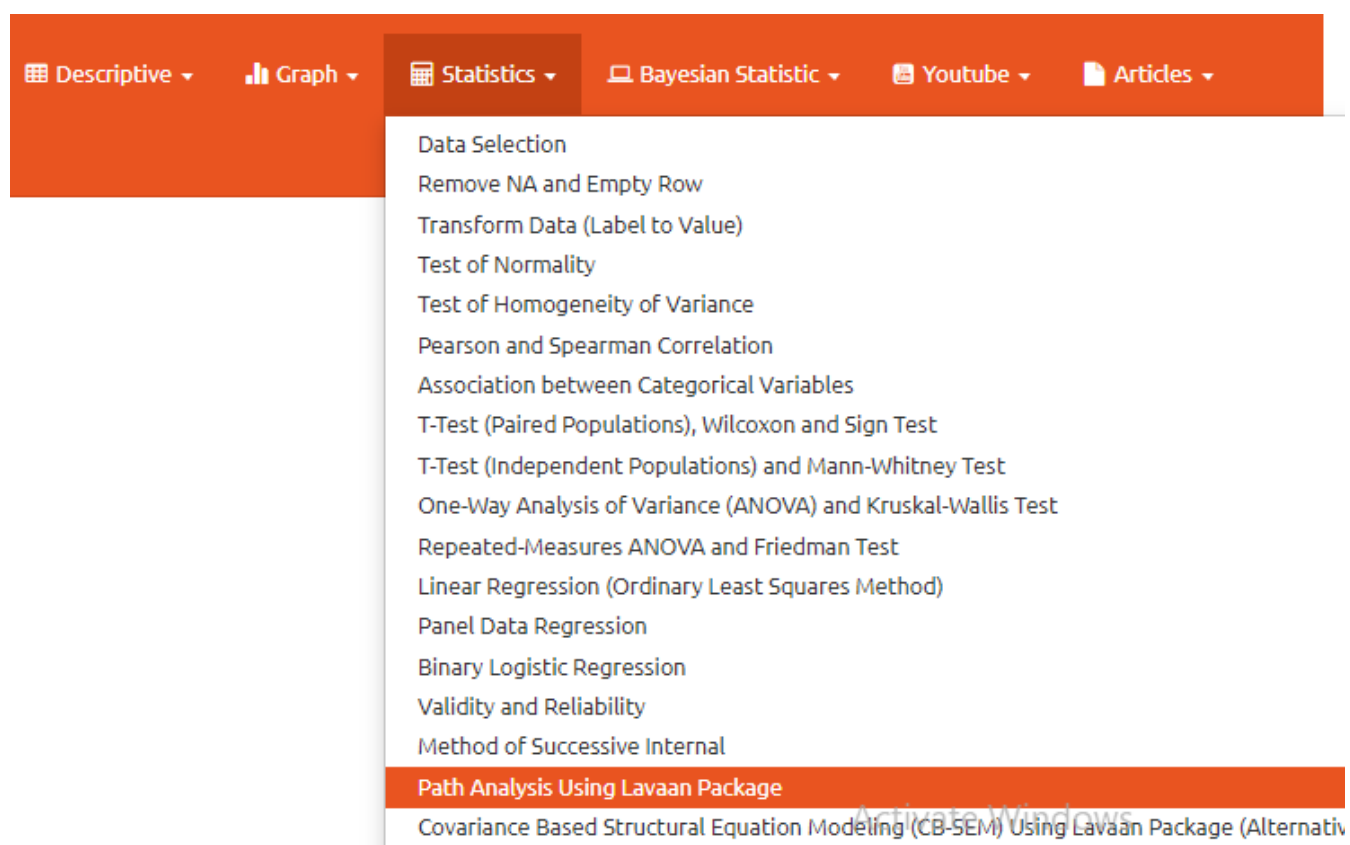

\title{
Gambar 18.1 Path Analysis Using Lavaan Package
}

\section{Path Analysis with Lavaan Package}

\begin{abstract}
Path Analysis
Enter Data \& Define Model

Result

Path Analysis Model

Related Articles

Youtube
\end{abstract}

\section{Pult Your Date Bellow:}

Model:
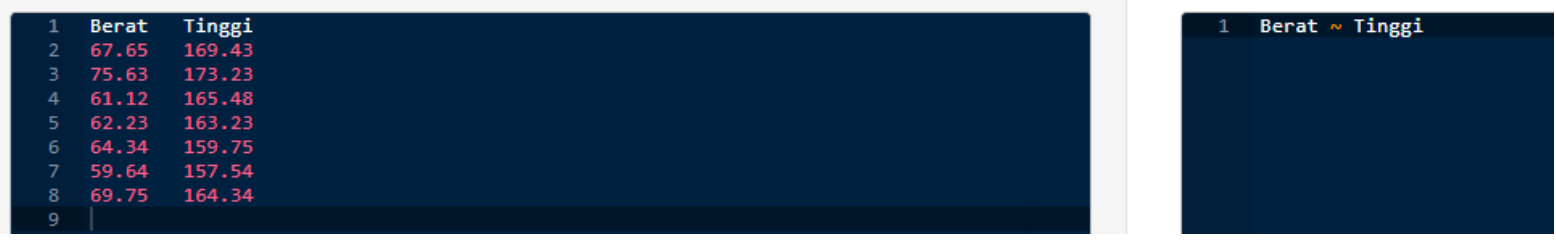

\section{Gambar 18.2 Input Data dan Mendefinisikan Model}

Selanjutnya perhatikan Gambar 18.2. Pada Gambar 18.2, input data pada Tabel 18.1 di bagian

Put Your Data Below:. Selanjutnya definisikan model di bagian Model:. Perhatikan bahwa

$$
\text { Berat } \sim \text { Tinggi }
$$

dapat diartikan:

$\Rightarrow$ Posisi variabel berat terletak di sebelah kiri tanda “ " yang berarti variabel berat sebagai variabel yang dipengaruhi atau dependen atau endogen. 
$\Rightarrow$ Sementara posisi variabel tinggi terletak di sebelah kanan tanda “ $~ "$ yang berarti variabel tinggi sebagai variabel yang mempengaruhi atau independen atau eksogen. Hasilnya dapat dilihat pada bagian Result.

\section{Path Analysis with Lavaan Package}

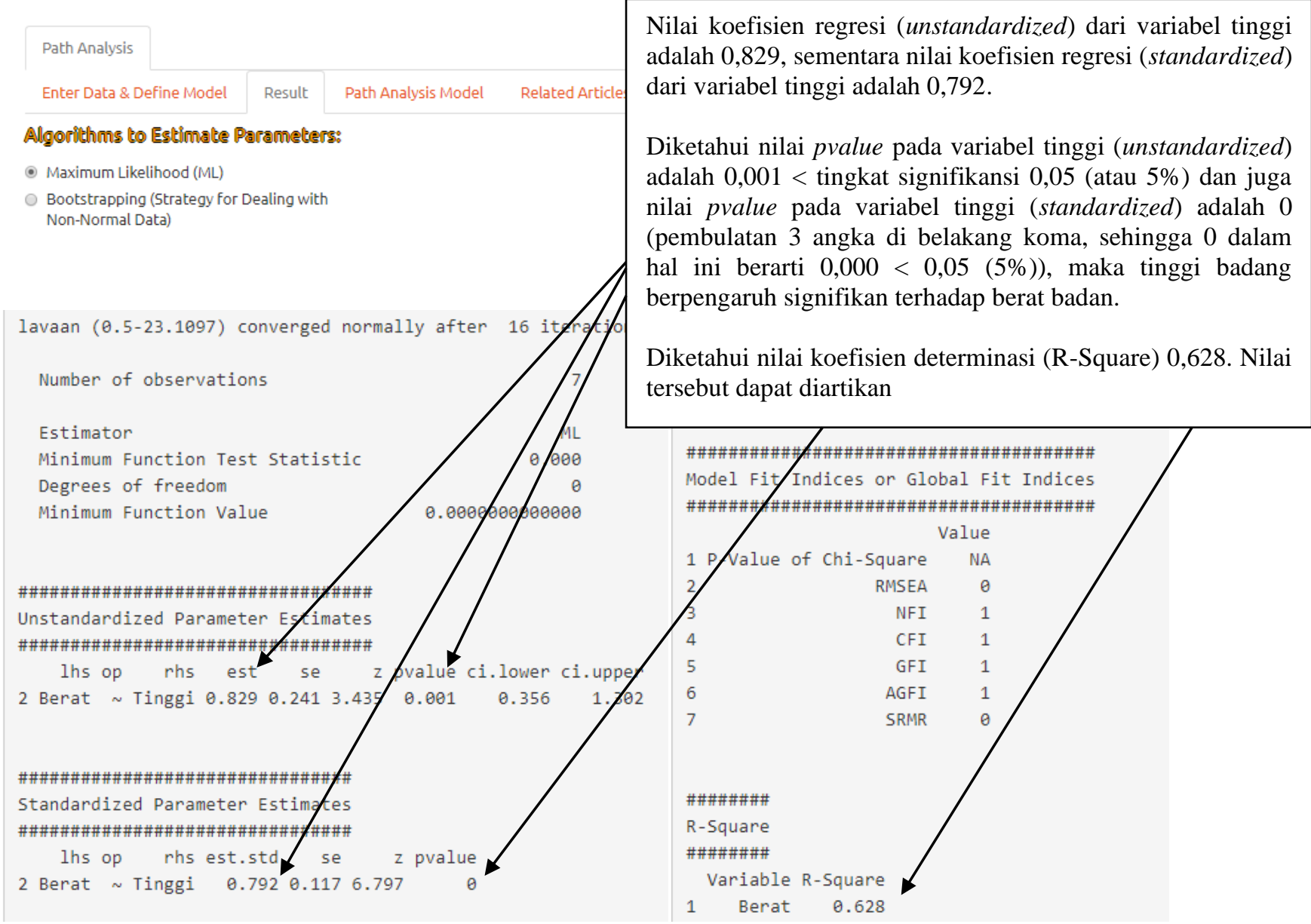

\section{Gambar 18.3 Hasil STATCAL: Path Analysis}

Berdasarkan hasil STATCAL pada Gambar 18.3 diketahui:

$\Rightarrow$ Nilai koefisien regresi (unstandardized) dari variabel tinggi adalah 0,829 , sementara nilai koefisien regresi (standardized) dari variabel tinggi adalah 0,792 . Diketahui kedua nilai koefisien regresi tersebut bernilai positif yang berarti tinggi berpengaruh positif terhadap berat. Semakin meningkat tinggi badan seseorang, berat badan juga cenderung meningkat (secara rata-rata). 
$\Rightarrow$ Diketahui nilai pvalue pada variabel tinggi (unstandardized) adalah $0,001<$ tingkat signifikansi 0,05 (atau 5\%) dan juga nilai pvalue pada variabel tinggi (standardized) adalah 0 (pembulatan 3 angka di belakang koma, sehingga 0 dalam hal ini berarti $0,000<0,05(5 \%))$, maka tinggi badang berpengaruh signifikan terhadap berat badan.

$\Rightarrow$ Diketahui nilai koefisien determinasi (R-Square) 0,628. Nilai tersebut dapat diartikan variabel tinggi badan mampu menjelaskan (variation) berat badan sebesar 62,8\%.

Tabel 18.2 merupakan hasil berdasarkan SPSS.

Tabel 18.2 Hasil berdasarkan Software SPSS

\begin{tabular}{|c|c|c|c|c|c|c|}
\hline \multicolumn{7}{|c|}{ Coefficients $^{a}$} \\
\hline \multirow{2}{*}{\multicolumn{2}{|c|}{ Model }} & \multicolumn{2}{|c|}{ Unstandardized Coefficients } & \multirow{2}{*}{$\begin{array}{c}\begin{array}{c}\text { Standardized } \\
\text { Coefficients }\end{array} \\
\text { Beta }\end{array}$} & \multirow[b]{2}{*}{$\mathrm{t}$} & \multirow[b]{2}{*}{ Sig. } \\
\hline & & B & Std. Error & & & \\
\hline \multirow[t]{2}{*}{1} & (Constant) & -70.813 & 47.062 & & -1.505 & .193 \\
\hline & Tinggi & .829 & .286 & .792 & 2.903 & .034 \\
\hline
\end{tabular}

Berdasarkan hasil software SPSS pada Tabel 18.2, diketahui:

$\Rightarrow$ Nilai koefisien regresi (kolom B atau unstandardized) dari variabel tinggi adalah 0,829, sementara nilai koefisien regresi (kolom Beta atau standardized) dari variabel tinggi adalah 0,792 . 
Gambar 18.4 disajikan hasil berdasarkan software LISREL.

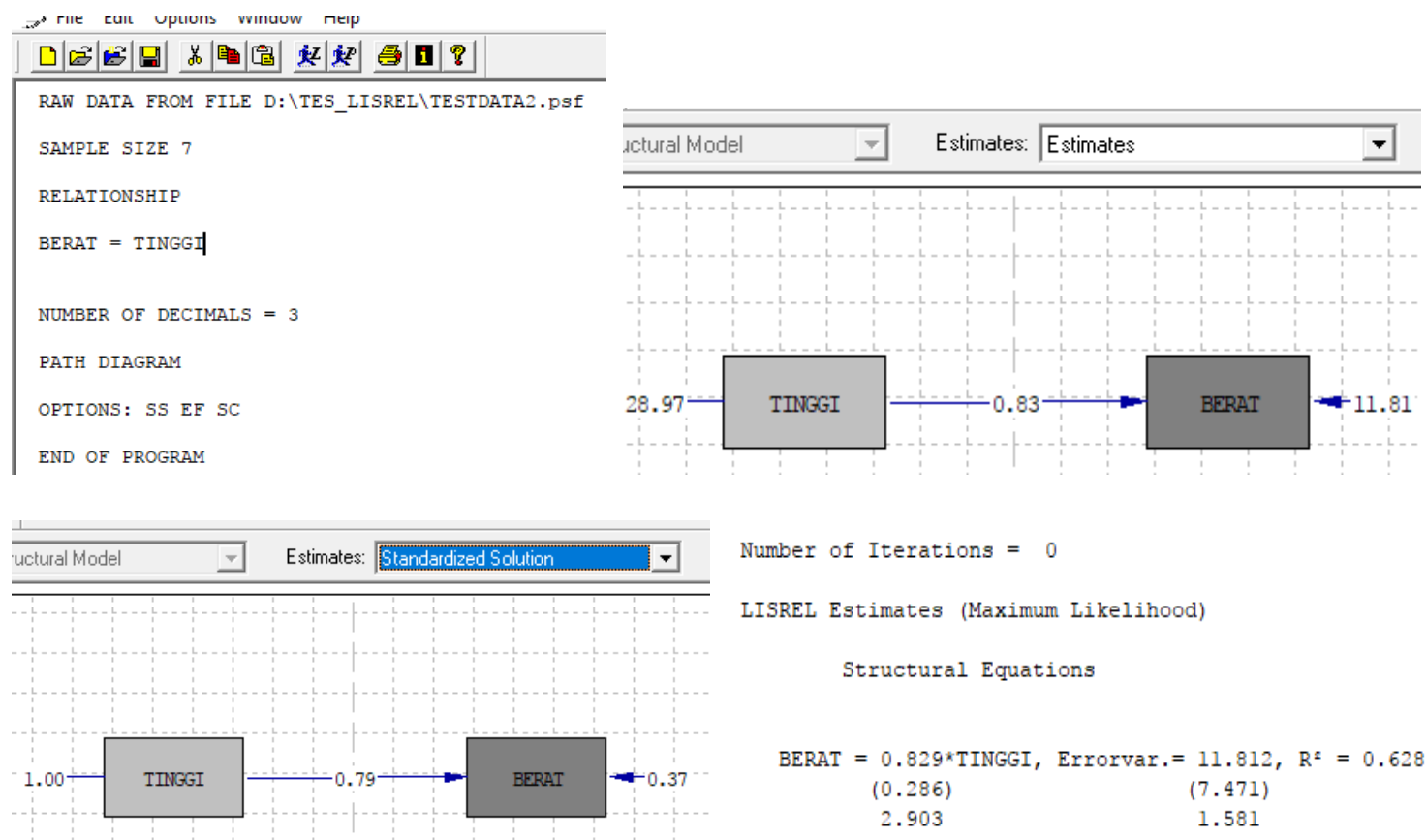

Gambar 18.4 Hasil berdasarkan Software LISREL

Tabel 18.3 disajikan perbandingan hasil antara STATCAL, LISREL dan SPSS.

Tabel 18.3 Perbandingan Hasil antara STATCAL, LISREL dan SPSS

\begin{tabular}{|c|c|c|c|c|c|}
\hline $\begin{array}{c}\text { Program } \\
\text { Aplikasi }\end{array}$ & $\begin{array}{c}\text { Koefisien Regresi Tinggi (Tidak } \\
\text { Baku) }\end{array}$ & $\begin{array}{c}\text { Koefisien Regresi Tinggi } \\
(\text { Baku })\end{array}$ & $\begin{array}{c}\text { T- } \\
\text { Value }\end{array}$ & $\begin{array}{c}\text { Z- } \\
\text { Value }\end{array}$ & $\begin{array}{c}\text { P- } \\
\text { Value }\end{array}$ \\
\hline STATCAL & 0.829 & 0.792 & & 3.181 & 0.001 \\
\hline LISREL & 0.829 & 0.792 & 2.903 & & \\
\hline SPSS & 0.829 & 0.792 & 2.903 & & 0.034 \\
\hline
\end{tabular}

Berdasarkan Tabel 18.3, diketahui bahwa dari nilai koefisien regresi variabel tinggi, baik untuk yang tidak baku (unstandardized) dan yang baku (standardized), untuk ketiga program aplikasi bernilai sama. Nilai T-Value LISREL dan SPSS sama dan nilai tersebut mendekati nilai Z-Value STATCAL. 
Perhatikan bahwa apabila asumsi normalitas tidak dipenuhi, maka pengujian signifikansi dapat menggunakan pendekatan bootstrapping (Gambar 18.6).

\section{Path Analysis with Lavaan Package}

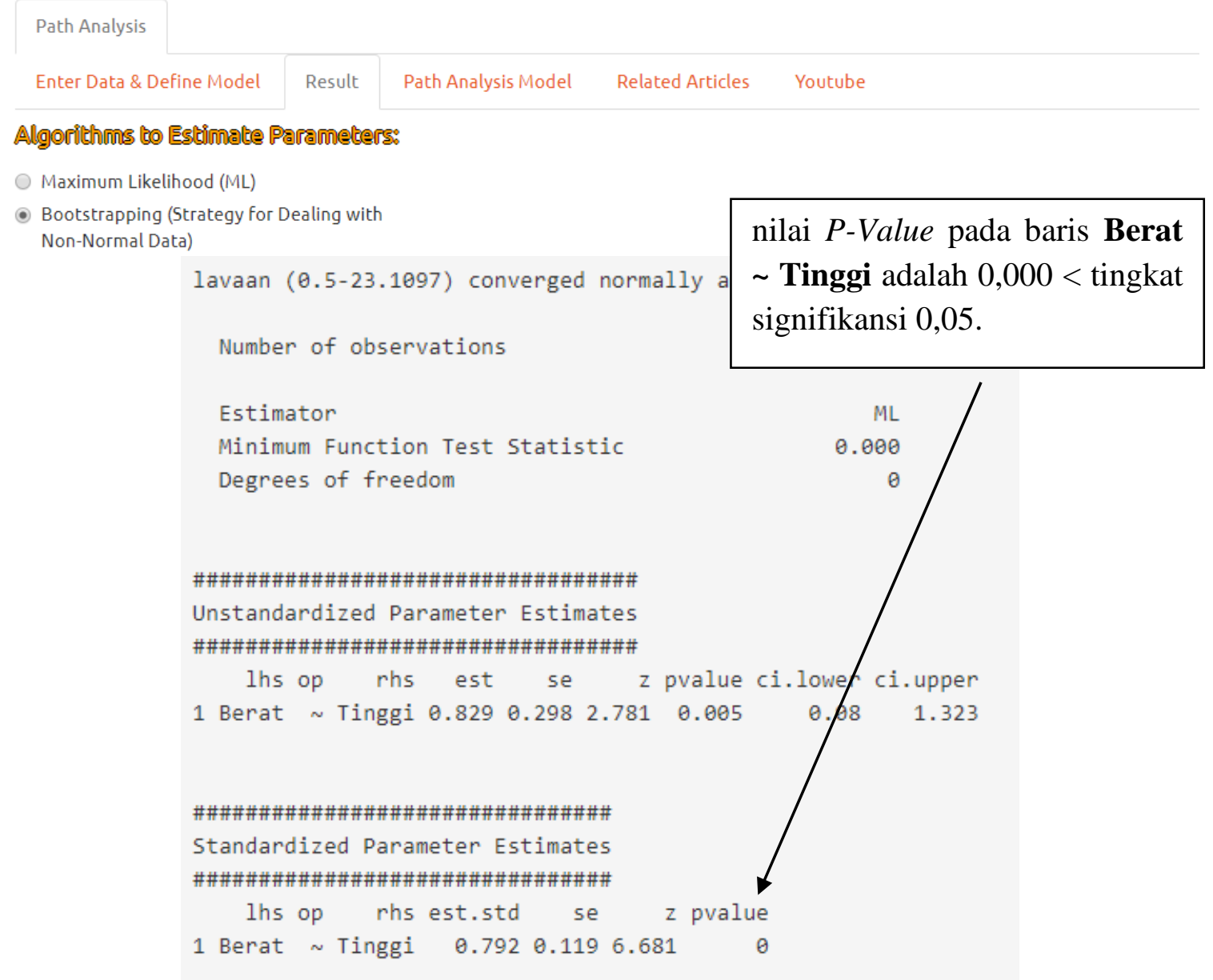

\section{Gambar 18.5 Uji Signifikansi dengan Pendekatan Bootstrapping (Alternatif Ketika Asumsi Normalitas Tidak Dipenuhi)}

Berdasarkan hasil pada Gambar 18.5, diketahui nilai P-Value pada baris Berat $\sim$ Tinggi adalah $0,000<$ tingkat signifikansi 0,05 , maka variabel tinggi berpengaruh signifikan terhadap berat. Yvess Rosseel (2012:26-27) dalam tulisannya "lavaan: An R Package for Structural Equation Modeling” (Journal of Statistical Software) menyatakan sebagai berikut. 
"7.1. Non-normal and categorical data The 0.4 version of the lavaan package only supports continuous data. Support for categorical data is expected in the 0.5 release. In the current release, however, I have devoted considerable attention to dealing with non-normal continuous data. In the SEM literature, the topic of dealing with non-normal data is well studied (see Finney and DiStefano 2006, for an overview). Three popular strategies to deal with non-normal data have been implemented in the lavaan package: asymptotically distribution-free estimation; scaled test statistics and robust standard errors; and bootstrapping."

Schumacker dan Lomax (2010:143) menyatakan berkaitan tentang analisis jalur sebagai berikut.

"In this chapter we consider path models, the logical extension of multiple regression models. Although path analysis still uses models involving multiple observed variables, there may be any number of independent and dependent variables and any number of equations. Thus, as we shall see, path models require the analysis of several multiple regression equations using observed variables.

Sewall Wright is credited with the development of path analysis as a method for studying the direct and indirect effects of variables (Wright, 1921, 1934, 1960). Path analysis is not actually a method for discovering causes; rather, it tests theoretical relationships, which historically has been termed causal modeling."

Gio dan Elly (2016:553) berdasarkan uraian di atas, dapat ditarik informasi bahwa model analisis jalur (path models) merupakan perluasan dari model regresi linear berganda. Dalam model regresi linear berganda, variabel tak bebas yang dilibatkan hanya satu (hanya terdapat satu persamaan), sementara pada model analisis jalur terdapat kemungkinan memiliki variabel tak bebas lebih dari satu, sehingga terdapat beberapa persamaan. Model analisis jalur yang melibatkan variabel tak bebas lebih dari satu, melibatkan penggunaan teknik regresi berganda lebih dari satu kali, untuk mengestimasi koefisien jalur. Jadi dalam hal ini, teknik regresi berganda dapat digunakan untuk menentukan koefisien jalur. Selanjutnya, metode analisis jalur dapat diartikan juga sebagai suatu metode untuk mempelajari pengaruh/efek langsung (direct effect) dan pengaruh tidak langsung (indirect effect) antara satu variabel dengan variabel lainnya. 
Misalkan diberikan diagram jalur (path diagram) dan persamaan untuk model regresi (Gambar 18.6), serta diagram jalur dan persamaan untuk model mediasi dengan satu variabel mediator (Gambar 18.7) (Mackinon, 48-49:2008).

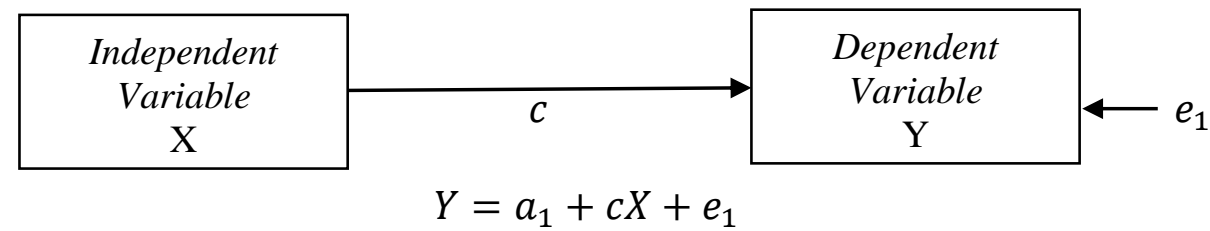

\section{Gambar 18.6 Diagram Jalur dan Persamaan untuk Model Regresi}

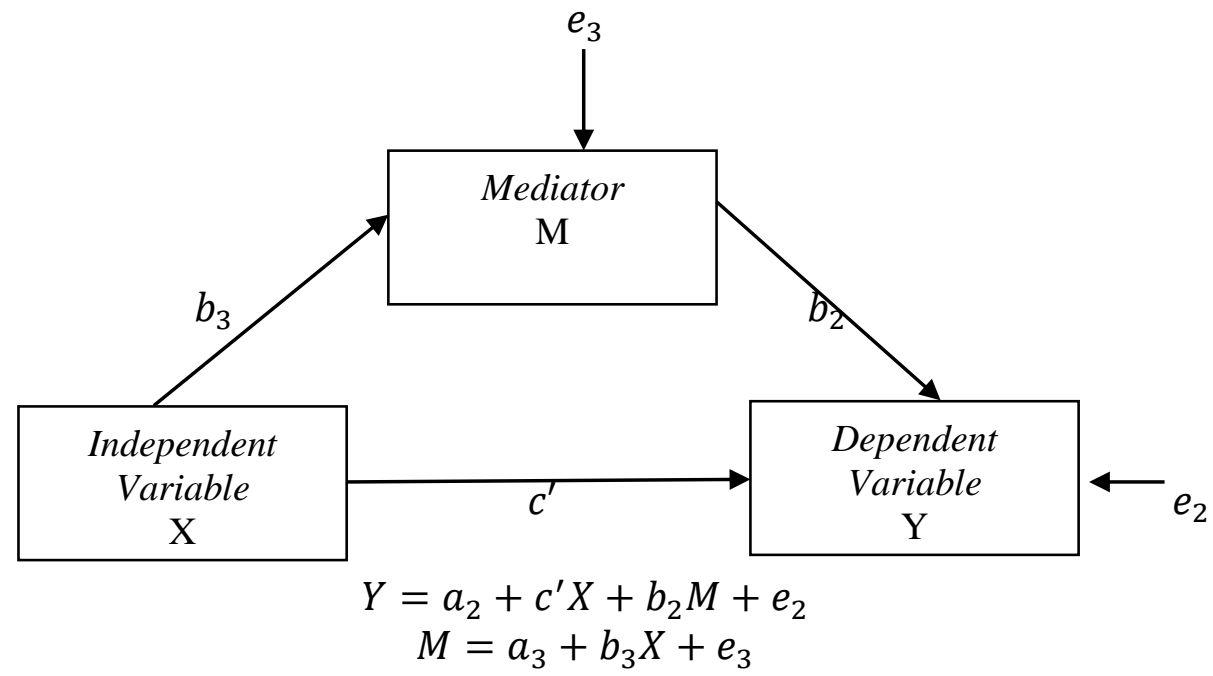

\section{Gambar 18.7 Diagram Jalur dan Persamaan untuk Model Mediasi dengan Satu Variabel Mediator}

Berdasarkan Gambar 18.6 dan Gambar 18.7, diperoleh 3 persamaan, yakni

$$
\begin{gathered}
Y=a_{1}+c X+e_{1} \\
Y=a_{2}+c^{\prime} X+b_{2} M+e_{2} \quad[18.1] \\
M=a_{3}+b_{3} X+e_{3} \quad[18.3] .
\end{gathered}
$$

MacKinnon (50:2008) menyatakan sebagai berikut.

"The intercepts are not involved in the estimation of mediated effects and could be left out of the equations. However, they are included here because intercepts are important for other aspects of mediation such as plotting the mediated effect. Note that both $c$ and $c^{\prime}$ are parameters relating the independent variable to the dependent variable, but $c^{\prime}$ is a partial effect, adjusted for the effects of the mediator. The parameters of this model can be estimated by multiple regression. Equation 3.1 defines the total effect model in figure 3.1, and Equations 3.2 and 3.3 define the mediation model in figure 3.2." 
Gio dan Elly (2016:555) berdasarkan uraian oleh Mackinnon, intersep-intersep tidak dilibatkan untuk mengestimasi efek mediasi (mediated effects). Namun, intersep-intersep tersebut berguna untuk aspek yang lain dari mediasi, yakni memplot (grafik) efek mediasi. Nilai-nilai parameter dari model tersebut $\left(b_{3}, c, b_{2}, c^{\prime}\right.$, dan seterusnya) dapat diestimasi dengan menggunakan regresi berganda (multiple regression). Perhatikan bahwa pengaruh tak langsung atau pengaruh mediasi (indirect effect atau mediated effect) dari variabel X terhadap variabel $\mathrm{Y}$, melalui variabel $\mathrm{M}$, merupakan hasil perkalian $b_{3} \times b_{2}$. Pengaruh langsung variabel $\mathrm{X}$ terhadap variabel $\mathrm{Y}$, dengan mengontrol variabel $\mathrm{M}$ adalah $c^{\prime}$. Parameterparameter seperti $b_{3}, b_{2}, c$, dan $c^{\prime}$ dapat diestimasi dengan menggunakan metode ordinary least squares regression (metode ordinary least squares regression tersedia dalam beberapa software, seperti SPSS, SAS, EViews, Minitab, dan sebagainya) (MacKinnon, 50-51:2008).

Gio dan Elly (2016:556-557) salah satu uji yang dapat digunakan untuk melakukan uj signifikansi pengaruh tidak langsung adalah uji Sobel. Pada uji Sobel menetapkan asumsi bahwa distribusi sampling dari $\boldsymbol{b}_{3} \times \boldsymbol{b}_{2}$ berdistribusi normal, di mana asumsi ini sering kali tidak terpenuhi. Lebih lanjut, pada uji Sobel memerlukan unstandardized path coefficient (koefisien-koefisien jalur yg tidak baku) sebagai input untuk menghitung nilai statistik dari uji Sobel $\left(z_{\text {Sobel }}\right)$ dan lacks statistical power, khususnya ketika jumlah elemen sampel kecil (Hair dkk., 223:2014; Preacher and Hayes, 2004). Hair dkk. (223:2014) menyatakan sebagai berikut.

"A commonly used approach for testing mediating effects is the Sobel (1982) test, which examines the relationship between the independent variable and the dependent variable compared with the relationship between the independent variable and dependent variable, including the mediation construct (Helm, Eggert, \& Garnefeld, 2010). However, this test relies on distributional assumptions, which usually do not hold for the indirect effect p12*p23 (specifically, the multiplication of two normally distributed coefficients results in a nonnormal distribution of their product). Furthermore, the Sobel test requires unstandardized path coefficients as input for the test statistic and lacks statistical power, especially when applied to small sample sizes." 
Sejalan dengan Hair dkk., Preacher dan Hayes (2004) menyatakan sebagai berikut.

"In order to conduct the test (Sobel test), ab is divided by $s_{a b}$ to yield a critical ratio that is traditionally compared with the critical value from the standard normal distribution appropriate for a given alpha level. One of the assumptions necessary for the Sobel test is that the sample size is large, so the rough critical value for the two-tailed version of the test, assuming that the sampling distribution of $a b$ is normal and that $\alpha=0,05$, is \pm 1.96 . As sample size becomes smaller, the Sobel test becomes less conservative."

Gio dan Elly (2016:556-557) oleh karena itu sebagai alternatif dapat digunakan pendekatan yang dikembangkan oleh Preacher dan Hayes (2004, 2008) dan bootstrap distribusi sampling dari koefisien pengaruh tak langsung. Pada pendekatan bootstrapping tidak memerlukan asumsi bentuk distribusi dari suatu variabel atau distribusi sampling dari suatu statistik, serta dapat diterapkan untuk ukuran sampel yang kecil (Hair dkk. 223:2014). Hair dkk (223:2014) menyatakan sebagai berikut.

"When testing mediating effects, researchers should rather follow Preacher and Hayes (2004, 2008) and bootstrap the sampling distribution of the indirect effect, which works for simple and multiple mediator models \{please note that we do not cover the latter case in this book; see Preacher \& Hayes, 2008). Bootstrapping makes no assumptions about the shape of the variables' distribution or the sampling distribution of the statistics and can be applied to small sample sizes with more confidence. The approach is therefore perfectly suited for the PLS-SEM method. In addition, the approach exhibits higher levels of statistical power compared with the Sobel test."

Gio dan Elly (2016:559) berdasarkan uraian pernyataan tersebut, diketahui beberapa perbedaan antara pendekatan model-fitting program (seperti LISREL, Amos) dan pendekatan regresi berganda (seperti pada SPSS, SAS, Minitab) adalah sebagai berikut.

$\Rightarrow$ Pada pendekatan model-fitting program menyajikan informasi mengenai overall fit of the model (kelayakan model secara keseluruhan), sementara pada regresi berganda (seperti pada SPSS, SAS, Minitab) tidak menyajikan informasi mengenai overall fit of the model. 
$\Rightarrow$ Pada pendekatan model-fitting program, selain menyajikan informasi mengenai overall fit of the model, juga menyajikan informasi total effect, direct effect, dan indirect effect, sementara pada regresi berganda (seperti pada SPSS, SAS, Minitab), perlu dihitung secara manual terlebih dahulu.

$\Rightarrow$ Pada pendekatan regresi berganda menggunakan metode estimasi parameter ordinary least squares (OLS) (seperti pada SPSS, SAS, Minitab), sementara pada pendekatan model-fitting program menggunakan metode estimasi parameter maximum likelihood (ML).

$\Rightarrow$ Pada pendekatan metode estimasi parameter OLS menghasilkan estimasi parameter secara one shot (tanpa iterasi atau pengulangan), sementara pada pendekatan metode estimasi parameter ML menghasilkan estimasi parameter melalui proses iterasi (iterative strategy).

$\Rightarrow$ Pada pendekatan regresi berganda mengestimasi parameter (koefisien jalur) dengan menyelesaikan persamaan untuk setiap variabel tak bebas (endogen) secara independen (independently), sementara pada pendekatan model-fitting program mengestimasi parameter (koefisien jalur) secara simultan (simultaneously) (all the paths of the entire model).

Gio dan Elly (2016:559) bagaimanapun, Meyers dkk. (599:2005) menegaskan bahwa hasil yang diperoleh berdasarkan dua pendekatan, yakni model-fitting program dan regresi berganda sering kali sangat mirip. Meyers dkk (599:2005) menyatakan sebagai berikut.

"However, we should note that the path analysis results produced by the two approaches are very often similar."

Misalkan diberikan data seperti pada Tabel 18.4. 
Tabel 18.4 Contoh Data

\begin{tabular}{|c|c|c|c|}
\hline Responden & Pelayanan & Kepuasan & Loyalitas \\
\hline 1 & 67 & 68 & 70 \\
\hline 2 & 68 & 68 & 66 \\
\hline 3 & 69 & 70 & 69 \\
\hline 4 & 72 & 69 & 69 \\
\hline 5 & 70 & 71 & 68 \\
\hline 6 & 68 & 68 & 71 \\
\hline 7 & 70 & 72 & 71 \\
\hline 8 & 67 & 69 & 71 \\
\hline 9 & 73 & 70 & 68 \\
\hline 10 & 69 & 71 & 74 \\
\hline 11 & 73 & 71 & 71 \\
\hline 12 & 70 & 67 & 70 \\
\hline 13 & 72 & 71 & 68 \\
\hline 14 & 74 & 75 & 75 \\
\hline 15 & 71 & 74 & 72 \\
\hline 16 & 70 & 67 & 65 \\
\hline 17 & 67 & 66 & 69 \\
\hline 18 & 72 & 71 & 74 \\
\hline 19 & 64 & 66 & 68 \\
\hline 20 & 69 & 67 & 69 \\
\hline 21 & 67 & 68 & 70 \\
\hline 22 & 72 & 71 & 66 \\
\hline 23 & 72 & 72 & 70 \\
\hline 24 & 69 & 66 & 69 \\
\hline 25 & 70 & 69 & 71 \\
\hline 26 & 69 & 71 & 71 \\
\hline 27 & 68 & 71 & 72 \\
\hline 28 & 75 & 73 & 71 \\
\hline 29 & 70 & 70 & 72 \\
\hline 30 & 69 & 68 & 70 \\
\hline 31 & 66 & 71 & 70 \\
\hline 32 & 67 & 70 & 70 \\
\hline 33 & 71 & 69 & 71 \\
\hline 34 & 69 & 71 & 67 \\
\hline 35 & 71 & 69 & 68 \\
\hline 36 & 71 & 72 & 68 \\
\hline 37 & 72 & 75 & 71 \\
\hline 38 & 70 & 69 & 74 \\
\hline 39 & 74 & 73 & 74 \\
\hline 40 & 69 & 72 & 71 \\
\hline 41 & 73 & 73 & 69 \\
\hline 42 & 71 & 67 & 70 \\
\hline 43 & 72 & 70 & 74 \\
\hline
\end{tabular}




\begin{tabular}{|l|l|l|l|}
\hline 44 & 70 & 70 & 69 \\
\hline 45 & 69 & 70 & 70 \\
\hline 46 & 71 & 72 & 70 \\
\hline 47 & 69 & 69 & 67 \\
\hline 48 & 70 & 70 & 69 \\
\hline 49 & 70 & 70 & 69 \\
\hline 50 & 69 & 67 & 69 \\
\hline
\end{tabular}

Model yang diuji seperti pada Gambar 18.8.

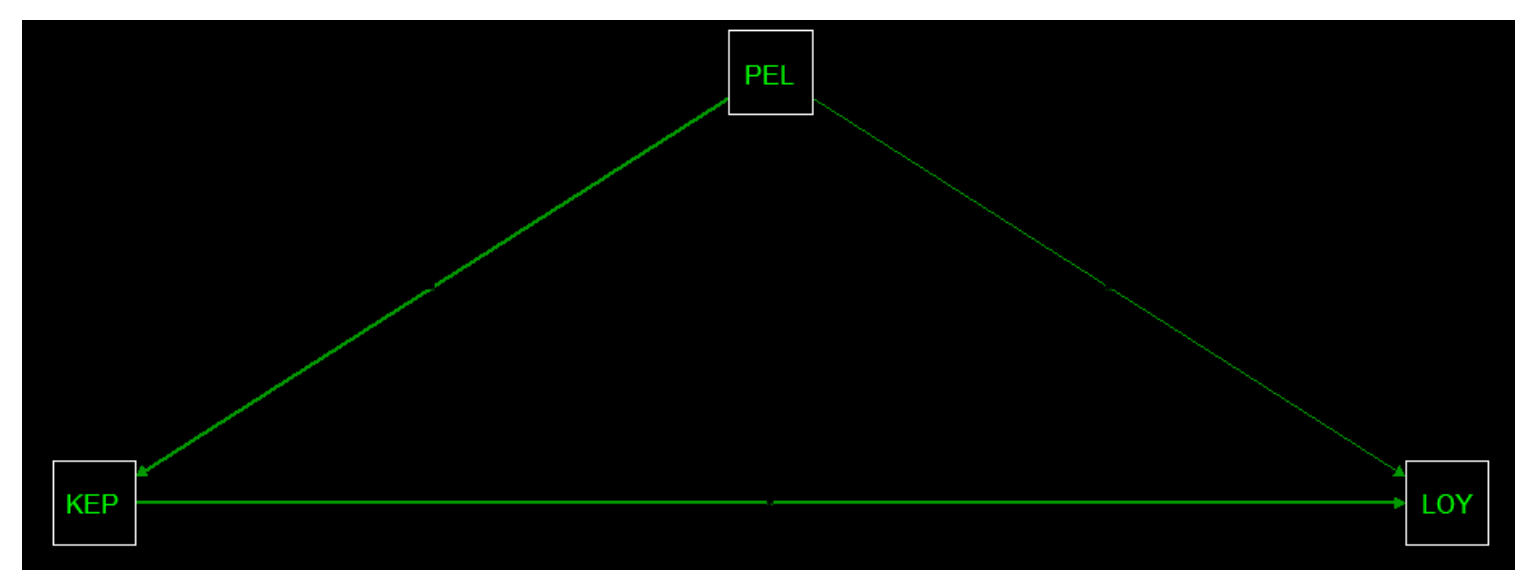

\section{Gambar 18.8 Model}

Berdasarkan model pada Gambar 18.8 akan diuji hipotesis:

$\Rightarrow$ Pelayanan berpengaruh positif dan signifikan terhadap kepuasan.

$\Rightarrow$ Pelayanan berpengaruh positif dan signfikan terhadap loyalitas

$\Rightarrow$ Kepuasan berpengaruh positif dan signifikan terhadap loyalitas.

$\Rightarrow$ Pelayanan secara tidak langsung signifikan mempengaruhi loyalitas, melalui kepuasan. Atau kepuasan signifikan memediasi pengaruh pelayanan terhadap loyalitas.

Pindahkan data pada Tabel 18.4 dan definisikan model seperti pada Gambar 18.9. 


\section{Put Your Datta Bellow:}

$\begin{array}{rlll}1 & \text { PEL } & \text { KEP } & \text { LOY } \\ 2 & 67 & 68 & 70 \\ 3 & 68 & 68 & 66 \\ 4 & 69 & 70 & 69 \\ 5 & 72 & 69 & 69 \\ 6 & 70 & 71 & 68 \\ 7 & 68 & 68 & 71 \\ 8 & 70 & 72 & 71 \\ 9 & 67 & 69 & 71 \\ 10 & 73 & 70 & 68 \\ 11 & 69 & 71 & 74 \\ 12 & 73 & 71 & 71 \\ 13 & 70 & 67 & 70\end{array}$

\section{Gambar 18.9 Input Data dan Mendefinisikan Model}

Berdasarkan Gambar 18.9, nilai koefisien jalur dari pelayanan menuju kepuasan dilambangkan huruf "a", sementara nilai koefisien jalur dari kepuasan menuju loyalitas dilambangkan dengan huruf "b".

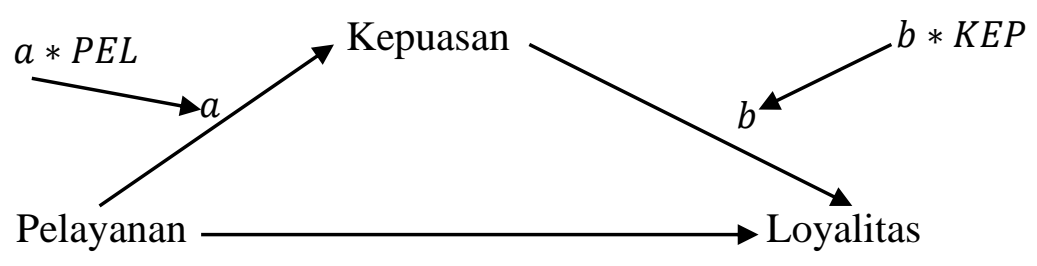

Gambar 18.10 Model

Perhatikan bahwa

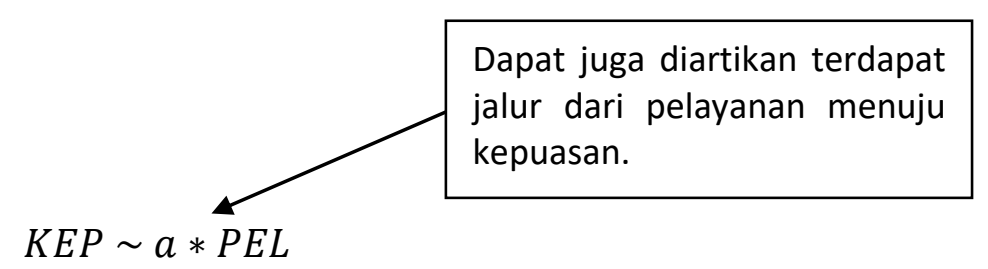

dapat diartikan:

$\Rightarrow$ Posisi variabel kepuasan terletak di sebelah kiri tanda “ ” yang berarti variabel kepuasan sebagai variabel yang dipengaruhi atau dependen atau endogen. 
$\Rightarrow$ Sementara posisi variabel pelayanan terletak di sebelah kanan tanda “ $\sim$ " yang berarti variabel pelayanan sebagai variabel yang mempengaruhi atau independen atau eksogen.

$\Rightarrow$ Huruf "a" merupakan nilai koefisien jalur dari pelayanan menuju kepuasan, yang nantinya digunakan untuk uji signifikansi pengaruh mediasi.

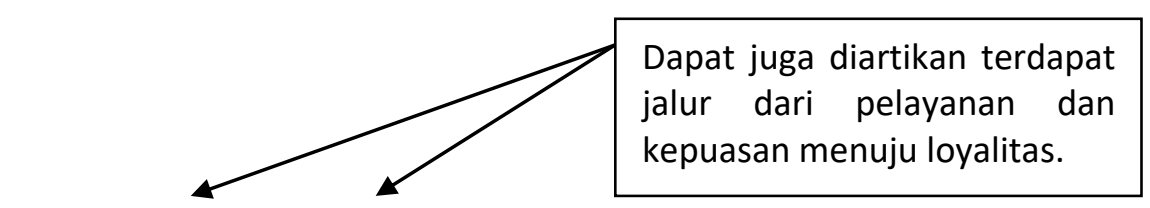

$$
L O Y \sim P E L+b * K E P
$$

dapat diartikan:

$\Rightarrow$ Posisi variabel loyalitas terletak di sebelah kiri tanda “ ” yang berarti variabel loyalitas sebagai variabel yang dipengaruhi atau dependen atau endogen.

$\Rightarrow$ Sementara posisi variabel kepuasan dan pelayanan terletak di sebelah kanan tanda “ $~$ yang berarti variabel kepuasan dan pelayanan sebagai variabel yang mempengaruhi atau independen atau eksogen.

$\Rightarrow$ Huruf "b" merupakan nilai koefisien jalur dari kepuasan menuju loyalitas, yang nantinya digunakan untuk uji signifikansi pengaruh mediasi.

Sementara $\boldsymbol{a b}:=\boldsymbol{a} * \boldsymbol{b}$ bertujuan untuk melakukan uji signifikansi kepuasan dalam memediasi pengaruh pelayanan terhadap loyalitas. Hasilnya dapat dilihat pada bagian Model (Gambar 18.11). 


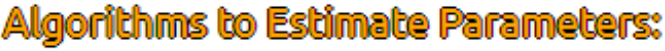

- Maximum Likelihood (ML)

Bootstrapping (Strategy for Dealing with Non-Normal Data)

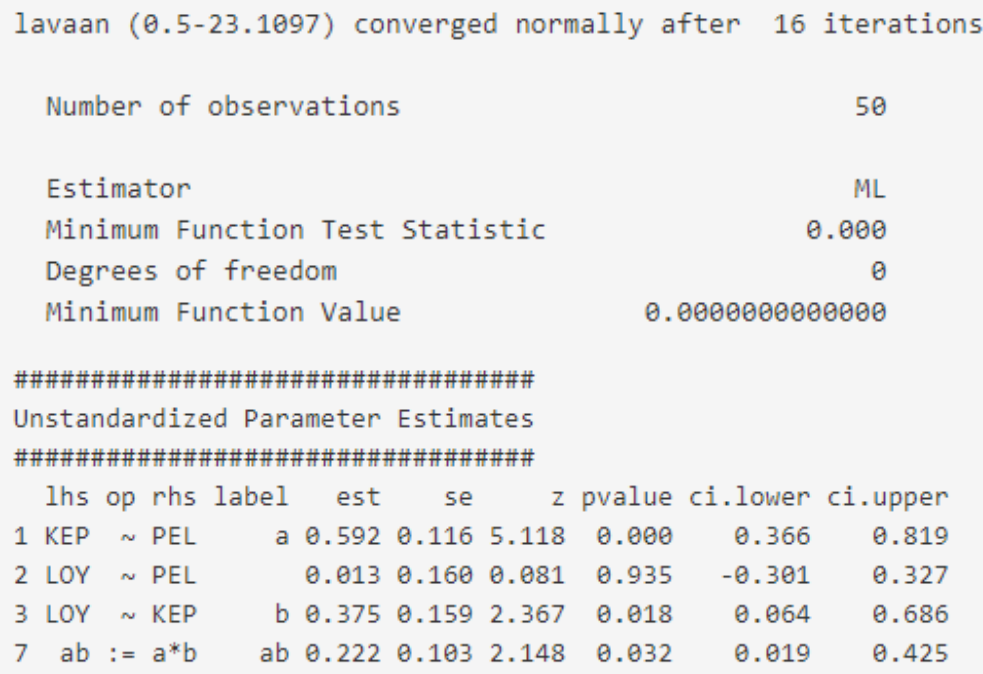

Baris $\mathbf{a b}:=\mathbf{a} * \mathbf{b}$ menyatakan pengaruh tidak langsung pelayanan terhadap loyalitas melalui kepuasan, yakni 0,223 dengan pvalue $0,021<0,05$, maka kepuasan signifikan memediasi hubungan antara pelayanan terhadap loyalitas.

\section{Gambar 18.11 Hasil STATCAL: Path Analysis}


Berdasarkan hasil analisis jalur pada Gambar 18.11 diperoleh hasil sebagai berikut:

$\Rightarrow$ Nilai koefisien jalur dari pelayanan menuju kepuasan (standardized) adalah 0,586.

Nilai koefisien jalur yang bernilai positif berarti pelayanan berpengaruh positif terhadap kepuasan. Diketahui nilai pvalue adalah 0,000 < tingkat signifikansi 5\%, maka pelayanan berpengaruh signifikan terhadap kepuasan.

$\Rightarrow$ Nilai koefisien jalur dari pelayanan menuju loyalitas (standardized) adalah 0,013. Nilai koefisien jalur yang bernilai positif berarti pelayanan berpengaruh positif terhadap loyalitas. Diketahui nilai pvalue adalah 0,935 > tingkat signifikansi 5\%, maka pelayanan tidak berpengaruh signifikan terhadap loyalitas.

$\Rightarrow$ Nilai koefisien jalur dari kepuasan menuju loyalitas adalah 0,381 (standardized). Nilai koefisien jalur yang bernilai positif berarti kepuasan berpengaruh positif terhadap loyalitas. Diketahui nilai pvalue adalah $0,018<$ tingkat signifikansi 5\%, maka kepuasan berpengaruh signifikan terhadap loyalitas.

$\Rightarrow$ Diketahui nilai koefisien determinasi (R-Square) pada kepuasan adalah 0,344. Nilai tersebut dapat diartikan variabel pelayanan mampu menjelaskan (variation) kepuasan sebesar $34,4 \%$.

$\Rightarrow$ Diketahui nilai koefisien determinasi (R-Square) pada loyalitas adalah 0,151. Nilai tersebut dapat diartikan variabel pelayanan dan kepuasan mampu menjelaskan (variation) loyalitas sebesar $15,1 \%$.

$\Rightarrow$ Untuk pengujian pengaruh tidak langsung, perhatikan baris ab :=a*b. Diketahui pengaruh tidak langsung pelayanan terhadap loyalitas, melalui kepuasan adalah 0,223 dengan nilai pvalue $0,021<$ tingkat signifikansi 0,05 . Maka kepuasan signifikan dalam memediasi pengaruh kepuasan terhadap loyalitas, pada tingkat signifikansi 5\%. 
Tabel 18.5 Ringkasan Hasil

\begin{tabular}{|c|c|c|}
\hline Pengaruh & Pengaruh Langsung & Pengaruh Tidak Langsung \\
\hline Pelayanan -> Kepuasan & $0,586(0,000<0,05$, Signifikan $)$ & \\
\hline Pelayanan -> Loyalitas & $\begin{array}{c}0,013(0,935>0,05, \text { Tidak } \\
\text { Signifikan) }\end{array}$ & \\
\hline Kepuasan -> Loyalitas & $0,381(0,018<0,05$, Signifikan $)$ & \\
\hline Pelayanan -> Kepuasan -> Loyalitas & & $\begin{array}{c}0,223(0,021<0,05, \\
\text { Signifikan) }\end{array}$ \\
\hline
\end{tabular}

Path analysis pada STATCAL menggunakan $R$ package lavaan. Perhatikan Gambar 18.12.

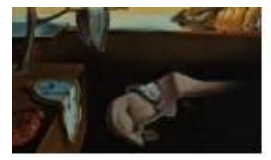

\title{
Journal of Statistical Software
}

May 2012, Volume 48, Issue 2.

http://www.jstatsoft.org/

\section{lavaan: An R Package for Structural Equation Modeling}

Yves Rosseel

Ghent University

\begin{abstract}
Structural equation modeling (SEM) is a vast field and widely used by many applied researchers in the social and behavioral sciences. Over the years, many software packages for structural equation modeling have been developed, both free and commercial. However, perhaps the best state-of-the-art software packages in this field are still closedsource and/or commercial. The $\mathrm{R}$ package lavaan has been developed to provide applied researchers, teachers, and statisticians, a free, fully open-source, but commercial-quality package for latent variable modeling. This paper explains the aims behind the development of the package, gives an overview of its most important features, and provides some examples to illustrate how lavaan works in practice.
\end{abstract}

\section{Gambar 18.12 R Package Lavaan}

Lavaan merupakan salah satu $R$ package, yang dikembangkan oleh Yves Rosseel, menyediakan fungsi untuk melakukan structural equation modeling. Yves Rosseel (2018:32) menyatakan sebagai berikut. 
"ML estimation: Wishart versus Normal If maximum likelihood estimation is used ("ML" or any of its robusts variants), the default behavior of lavaan is to base the analysis on the so-called biased sample covariance matrix, where the elements are divided by $n$ instead of $n-1$.

This is done internally, and should not be done by the user. In addition, the chi-square statistic is computed by multiplying the minimum function value with a factor $n$ (instead of $n-1)$. This is similar to the Mplus program.

If you prefer to use an unbiased covariance, and n-1 as the multiplier to compute the chisquare statistic, you need to specify the likelihood = "wishart" argument when calling the fitting functions. For example:

fit $<-c f a(H S . m o d e l$,

data $=$

HolzingerSwineford

1939, likelihood $=$

"wishart")

fit

The value of the test statistic will be closer to the value reported by programs like EQS, LISREL or AMOS, since they all use the 'Wishart' approach when using the maximum likelihood estimator. The program Mplus, on the other hand, uses the 'normal' approach to maximum likelihood estimation."

Berdasarkan kutipan di atas, diperoleh informasi bahwasannya estimasi Maximum Likelihood dalam $R$ package lavaan, terdapat dua alternatif pilihan, yakni wishart dan normal. Hasil SEM atau path analysis pada $R$ package lavaan dengan pilihan wishart akan mendekati hasil pada software seperti EQS, LISREL dan AMOS, dikarenakan pada software tersebut menggunakan pilihan wishart. Namun pada software Mplus menggunakan pendekatan 'normal' ('normal' approach) untuk estimasi maximum likelihood. 
Misalkan diberikan data dan model seperti berikut.

Tabel 18.6 Contoh Data

\begin{tabular}{|c|c|c|c|}
\hline Responden & Pelayanan & Kepuasan & Loyalitas \\
\hline 1 & 67 & 68 & 70 \\
\hline 2 & 68 & 68 & 66 \\
\hline 3 & 69 & 70 & 69 \\
\hline 4 & 72 & 69 & 69 \\
\hline 5 & 70 & 71 & 68 \\
\hline 6 & 68 & 68 & 71 \\
\hline 7 & 70 & 72 & 71 \\
\hline 8 & 67 & 69 & 71 \\
\hline 9 & 73 & 70 & 68 \\
\hline 10 & 69 & 71 & 74 \\
\hline 11 & 73 & 71 & 71 \\
\hline 12 & 70 & 67 & 70 \\
\hline 13 & 72 & 71 & 68 \\
\hline 14 & 74 & 75 & 75 \\
\hline 15 & 71 & 74 & 72 \\
\hline 16 & 70 & 67 & 65 \\
\hline 17 & 67 & 66 & 69 \\
\hline 18 & 72 & 71 & 74 \\
\hline 19 & 64 & 66 & 68 \\
\hline 20 & 69 & 67 & 69 \\
\hline 21 & 67 & 68 & 70 \\
\hline 22 & 72 & 71 & 66 \\
\hline 23 & 72 & 72 & 70 \\
\hline 24 & 69 & 66 & 69 \\
\hline 25 & 70 & 69 & 71 \\
\hline 26 & 69 & 71 & 71 \\
\hline 27 & 68 & 71 & 72 \\
\hline 28 & 75 & 73 & 71 \\
\hline 29 & 70 & 70 & 72 \\
\hline 30 & 69 & 68 & 70 \\
\hline 31 & 66 & 71 & 70 \\
\hline 32 & 67 & 70 & 70 \\
\hline 33 & 71 & 69 & 71 \\
\hline 34 & 69 & 71 & 67 \\
\hline 35 & 71 & 69 & 68 \\
\hline 36 & 71 & 72 & 68 \\
\hline 37 & 72 & 75 & 71 \\
\hline 38 & 70 & 69 & 74 \\
\hline 39 & 74 & 73 & 74 \\
\hline 40 & 69 & 72 & 71 \\
\hline
\end{tabular}




\begin{tabular}{|l|l|l|l|}
\hline 41 & 73 & 73 & 69 \\
\hline 42 & 71 & 67 & 70 \\
\hline 43 & 72 & 70 & 74 \\
\hline 44 & 70 & 70 & 69 \\
\hline 45 & 69 & 70 & 70 \\
\hline 46 & 71 & 72 & 70 \\
\hline 47 & 69 & 69 & 67 \\
\hline 48 & 70 & 70 & 69 \\
\hline 49 & 70 & 70 & 69 \\
\hline 50 & 69 & 67 & 69 \\
\hline
\end{tabular}

Model yang diuji seperti pada Gambar 18.13.

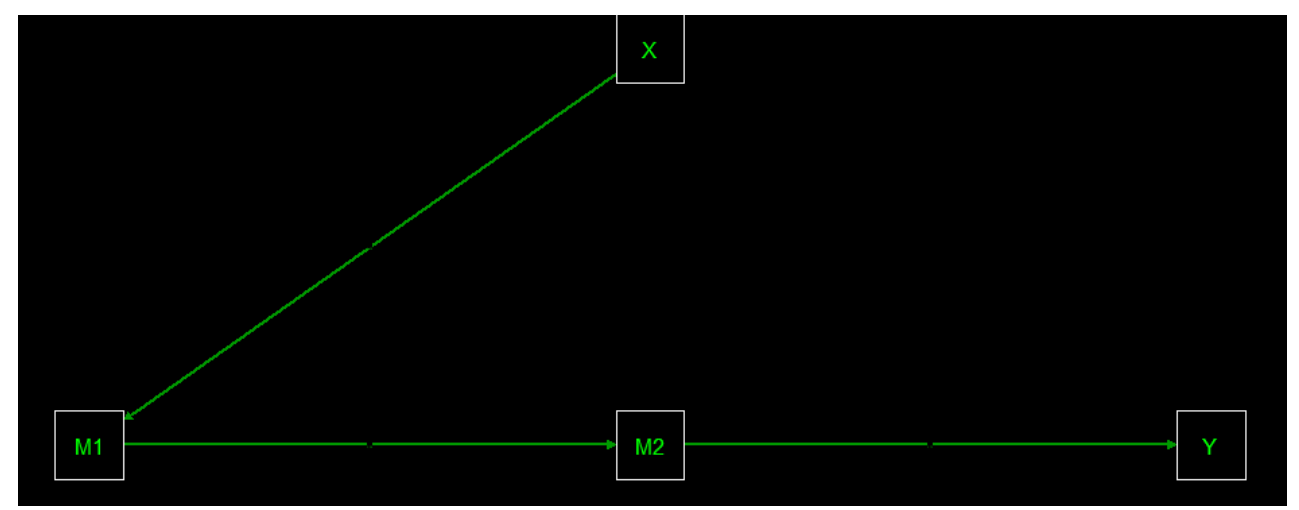

\section{Gambar 18.13 Model}

Berdasarkan model pada Gambar 18.13 akan apakah X secara tidak langsung signifikan mempengaruhi Y melalui M1 dan M2. Pindahkan data pada Tabel 18.16 dan definisikan model seperti pada Gambar 18.14. Hasil path analysis disajikan pada Gambar 18.15.

\section{Put Your Date Bellow:}

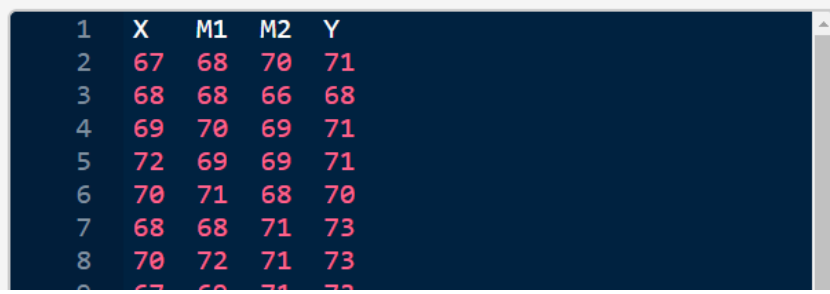

\section{Model:}

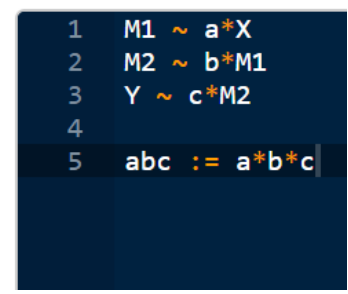

Gambar 18.14 Input Data dan Mendefinisikan Model 


\section{Algorithnns to Estinnatte Paranetters:}

- Maximum Likelihood (ML)

Bootstrapping (Strategy for Dealing with Non-Normal Data)

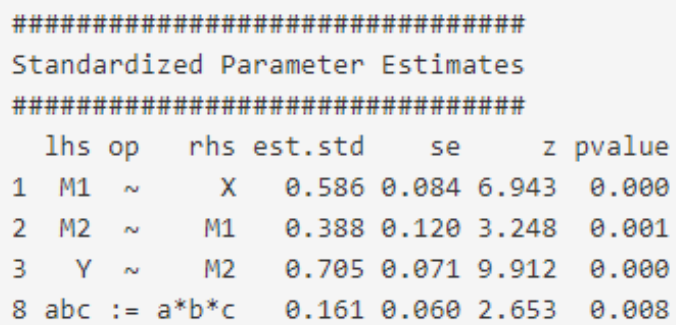

\#\#\#\#\#\#\#\#\#\#\#\#\#\#\#\#\#\#\#\#\#\#\#\#\#\#\#\#\#\#\#\#\#\# Model Fit Indices or Global Fit Indices \#\#\#\#\#\#\#\#\#\#\#\#\#\#\#\#\#\#\#\#\#\#\#\#\#\#\#\#\#\#\#\#\#\#\# Value

1 P-Value of Chi-Square 0.9998

2 RMSEA 0.0000

NFI 0.9999

CFI 1.0000

GFI 0.9999

AGFI 0.9997

SRMR 0.8037
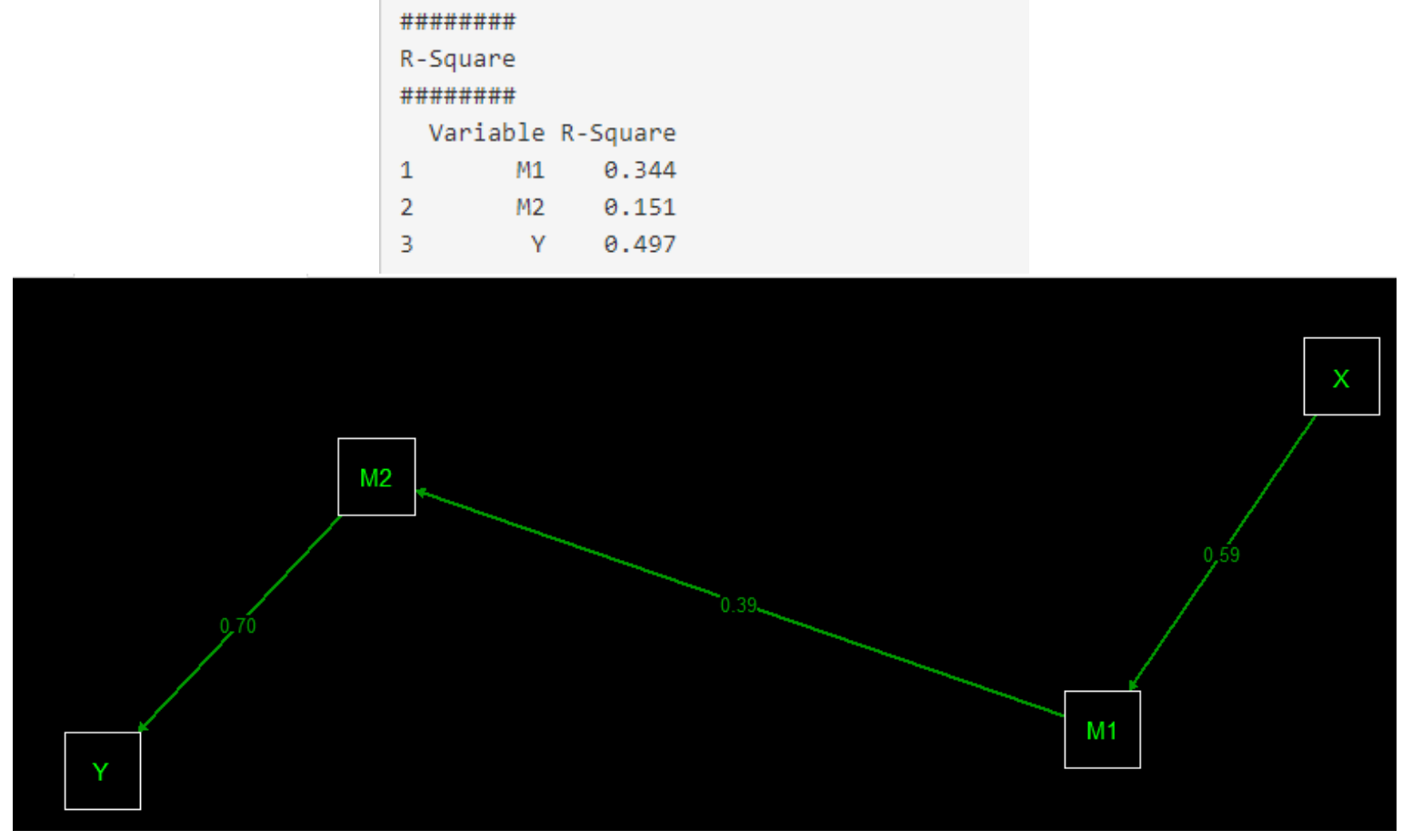

Gambar 18.15 Hasil STATCAL: Path Analysis 
Untuk pengujian pengaruh tidak langsung, perhatikan baris $\mathbf{a b c}:=\mathbf{a} * \mathbf{b} * \mathbf{c}$. Diketahui pengaruh tidak langsung X terhadap Y, melalui M1 dan B2 adalah 0,161 dengan nilai pvalue 0,008< tingkat signifikansi 0,05. Maka X1 secara tidak langsung signifikan mempengaruhi Y melalui M1 dan M2. 


\section{Referensi}

[1] John Maindonald dan W. John Braun, 2010, Data Analysis and Graphics Using R, An Example-Based Approach $3^{\text {rd }}$ Edition, Cambridge University Press.

[2] Gareth James, Daniela Witten, Trevor Hastie dan Robert Tibshirani, 2014, An Introduction to Statistical Learning with Applications in R, Springer.

[3] Peter Dalgaard, 2008, Introductory Statistics with $R, 2^{\text {nd }}$ Edition, Springer.

[4] Michael J. Crawley, 2015, Statistics, An Introduction Using R, $2^{\text {nd }}$ Edition, John Wiley and Sons, Ltd.

[5] Sanders \& Smidth, 2000, Statistics, A First Course, $6^{\text {th }}$ Edition, McGraw-Hill.

[6] Douglas C. Montgomery dan George C. Runger, 2014, Applied Statistics and Probability for Engineers, $6^{\text {th }}$ Edition, John Wiley \& Sons.

[7] Alan Agresti dan Barbara Finlay, 2009, Statistical Methods for the Social Sciences, $4^{\text {th }}$ Edition, Prentice Hall.

[8] Andy Field, 2009, Discovering Statistics Using SPSS, $3^{\text {rd }}$ Edition, Sage.

[9] Damodar N. Gujarati, 2003, Basic Econometrics, ${ }^{\text {th }}$ Edition, McGraw-Hill.

[10] Prem S. Mann, 2013, Introductory Statistics, $8^{\text {th }}$ Edition, John Wiley and Sons.

[11] Murray R. Spiegel dan Larry J. Stephens, 2008, Statistics $4^{\text {th }}$ Edition, McGraw-Hill Companies.

[12] Jim Albert, 2009, Bayesian Computation with $R, 2^{\text {nd }}$ Edition, Springer.

[13] Nick T. Thomopoulos, 2013, Essentials of Monte Carlo Simulation, Statistical Methods for Building Simulation Models, Springer.

[14] Sugiyono, 2015, Metode Penelitian Manajemen, Penerbit ALFABETA.

[15] Yvonne Augustine dan Robert Kristaung, 2013, Metodologi Penelitian Bisnis dan Akuntansi, Dian Rakyat.

[16] W. J. Conover, 1999, Practical Nonparametric Statistics $3^{\text {rd }}$ Edition, John Wiley and Sons.

[17] Paul H. Kvam dan Brani Vidakovic, 2007, Nonparametric Statistics with Applications to Science and Engineering, John Wiley and Sons. 
[18] Baron, R. M dan Kenny, D. A., 1986. The Moderator-Mediator Variable Distinction in Social Psychological Research: Conceptual, Strategic, and Statistical Considerations. Journal of Personality and Social Psychology. Vol. 51, No. 6, 1173-1182. American Psychological Association, Inc.

[19] Hair, J.F Jr., R.E. Anderson, B.J. Babin, dan W.C. Black. 2010. Multivariate Data Analysis, $7^{\text {th }}$ Edition. Pearson Prentice Hall.

[20] Hair, J.F Jr., G.T.M. Hult, C.M. Ringle, dan M. Sarstedt. 2014. A Primer on Partial Least Squares Structural Equation Modeling (PLS-SEM). Sage.

[21] MacKinnon, D.P. 2008. Introduction to Statistical Mediation Analysis. Lawrence Erlbaum Associates.

[22] Meyers, L.S., G. Gamst, dan A.J. Guarino. 2005. Applied Multivariate Research, Design and Interpretation. Sage.

[23] Mindrila, D. 2010, Maximum Likelihood (ML) and Diagonally Weighted Least Squares (DWLS) Estimation Procedures: A Comparison of Estimation Bias with Ordinal and Multivariate Non-Normal Data, International Journal of Digital Society (IJDS), Volume 1, Issue 1.

[24] Preacher, K. J dan Hayes, A. F., 2004. SPSS and SAS Procedures for Estimating Indirect Effects in Simple Mediation Models. Behavior Research Methods, Instruments, \& Computers, 36 (4), 717-731. Psychonomic Society, Inc.

[25] Preacher, K. J dan Leonardelli, G. J., 2006. Calculation for the Sobel Test: An Interactive Calculation Tool for Mediation Tests. www.psych.ku.edu/ preacher/sobel/sobel.htm.

[26] Schumacker, R.E. dan R.G. Lomax. 2010. A Beginner's Guide to Structural Equation Modeling, $3^{\text {rd }}$ Edition. Rouletdge.

[27] Sholihin, M. dan D. Ratmono. 2013. Analisis SEM-PLS dengan WarpPLS 3.0 untuk Hubungan Nonlinear dalam Penelitian Sosial dan Bisnis. Penerbit ANDI.

[28] Gio, P.U. dan Elly, Rosmaini, 2016, Belajar Olah Data dengan SPSS, Minitab, R, Microsoft Excel, EViews, LISREL, AMOS dan SmartPLS, USUpress.

[29] Rosseel, Yves, 2018, The lavaan tutorial

[30] Haryono, Siswoyo, 2017, Metode SEM untuk Penelitian Manajemen AMOS, LISREL PLS, luxima. 
[31] Ghozali, Imam, 2013, Aplikasi Analisis Multivariate dengan Program IBM SPSS 22 Update PLS Regresi, Penerbit Universitas Diponegoro.

[32] Yves Rosseel (2012). lavaan: An R Package for Structural Equation Modeling. Journal of Statistical Software, 48(2), 1-36. URL http://www.jstatsoft.org/v48/i02/.

http://www.sthda.com/english/wiki/ggplot2-quick-correlation-matrix-heatmap-r-software-and-datavisualization

http://www.sthda.com/english/wiki/ggcorrplot-visualization-of-a-correlation-matrix-using-ggplot2

https://briatte.github.io/ggcorr/

http://jamesmarquezportfolio.com/correlation_matrices_in_r.html

http://a-little-book-of-r-for-time-series.readthedocs.io/en/latest/src/timeseries.html

https://www.r-bloggers.com/plotting-time-series-data-using-ggplot2/

https://www.statmethods.net/advstats/timeseries.html

https://plot.ly/r/time-series/

https://plot.ly/ggplot2/facet/

http://ggplot2.tidyverse.org/reference/facet_grid.html

http://cookbook-r.com/Graphs/Facets_(ggplot2)/

http://www.sthda.com/english/wiki/ggplot2-facet-split-a-plot-into-a-matrix-of-panels

https://www3.nd.edu/ steve/computing_with_data/13_Facets/facets.html

https://www3.nd.edu/ steve/computing_with_data/13_Facets/facets.html

http://sape.inf.usi.ch/quick-reference/ggplot2/facet

https://cran.r-project.org/web/packages/shinythemes/index.html

https://cran.r-project.org/web/packages/lavaan/index.html

https://cran.r-project.org/web/packages/plspm/index.html

https://cran.r-project.org/web/packages/ggplot2/index.html

https://cran.r-project.org/web/packages/reshape2/index.html

https://cran.r-project.org/web/packages/dplyr/index.html

https://cran.r-project.org/web/packages/shiny/index.html 
https://cran.r-project.org/web/packages/plyr/index.html https://cran.r-project.org/web/packages/DT/index.html https://cran.r-project.org/web/packages/doBy/index.html https://cran.r-project.org/web/packages/GGally/index.html https://cran.r-project.org/web/packages/plotrix/index.html https://cran.r-project.org/web/packages/tseries/index.html https://cran.r-project.org/web/packages/nortest/index.html https://cran.r-project.org/web/packages/car/index.html https://cran.r-project.org/web/packages/RVAideMemoire/index.html https://cran.r-project.org/web/packages/plm/index.html https://cran.r-project.org/web/packages/colourpicker/index.html https://cran.r-project.org/web/packages/psych/index.html https://cran.r-project.org/web/packages/DescTools/index.html https://cran.r-project.org/web/packages/semPlot/index.html 